\title{
The Effect of Dadiah Feeding of Breastfeeding Women With Normal Flora of Digestive Tract
}

\author{
Netti Suharti ${ }^{1}$, Linosefa ${ }^{2}$, Asih Kumala ${ }^{3}$, Eva Chundrayetti ${ }^{4}$, Andani Eka Putra ${ }^{5}$ \\ \{nettisuharti@med.unand.ac.id ${ }^{1}$ \} \\ Department of Microbiology, Faculty of Medicine, Universitas Andalas Padang, Indonesia ${ }^{1,2,5}$, \\ Biomedical Science Graduate Program, Faculty of Medicine, Universitas Andalas Padang, Indonesia ${ }^{3}$, \\ Department of Pediatrics, Faculty of Medicine, Universitas Andalas Padang, Indonesia ${ }^{4}$
}

\begin{abstract}
Dadiah is a fermented buffalo milk product containing many potential lactic acid bacteria as probiotics. Lactic acid bacteria and their derivative products can prevent the onset of various diseases such as spur health and heart work, good food to increase stamina and endurance, prevent colon cancer and improve intestinal microflora. The objective of this research is to see the effect of giving dadiah in the form of ice cream to the growth of L. plantarum in infant gastrointestinal tract. The study was conducted on 28 breastfeeding mothers who were divided into two groups with the same proportion, i.e. mothers who received dadiah ice cream and not. Interventions were performed for 1 month, and analysis was performed on the infant's feces. DNA isolated from feces and L. Plantarum concentrations were analyzed using real-time PCR. The standard curve is designed to get the concentration of bacteria appropriately. Data analysis using SPSS version 20.0 , numerical data were analyzed by using independent T-test and dependent $\mathrm{T}$ test. $P$-value of $<0.05$ was considered statistically significant. The results showed that the mean intestinal microflora of the infant before the dadiah ice cream was given was $4.2 \mathrm{x}$ $107 \mathrm{CFU} /$ gram and after the dadiah ice cream was $8.6 \times 108 \mathrm{CFU} / \mathrm{g}(\mathrm{p}<0.05)$ while in the control group, the mean L. Plantarum intestinal infants before administered whey ice cream is $2.6 \times 107 \mathrm{CFU} /$ gram and thereafter $1.3 \times 107 \mathrm{CFU} / \mathrm{g}(\mathrm{p}>0.05)$. Based on the results of this study it can be concluded that there is an increase in L.plantarum concentration after the provision of dadiah ice cream in breastfeeding mothers.
\end{abstract}

Keywords: Dadiah, Breastfeeding Mothers, Feces, Normal Flora, L. Plantarum.

\section{Introduction}

Dadiah is a fermented buffalo milk product originating from West Sumatra which is a traditional foodstuff [1]. The curd is a buffalo milk product fermented naturally in bamboo containers at room temperature for 24-48 hours. Dadiah is usually served by mixing with glutinous rice stick that has been flaked and added coconut milk and liquid sugar. The curd is also delicious to eat with hot rice and sauce [2].

From several studies, it is known that the dadiah contains potent lactic acid bacteria as probiotics. The probiotic bacteria contained in the curd are Lactobacillus and Bifidobacterium [3]. Lactic acid bacteria and their derivative products are able to prevent the onset of various diseases such as spurring health and the workings of the heart, a good food to increase stamina and endurance, prevent colon cancer, improve intestinal microflora, repair the intestinal condition affected by antibiotic treatment, treat diarrhea caused by antibiotics, viruses and 
bacteria, produce digestive enzymes, antimutagen, anticarcinogenic and effective as antivaginitis [4].

Probiotics will be effective if able to survive well in environmental conditions such as in the stomach that is low $\mathrm{pH}$ environment conditions and not damaged by enzymes produced by the stomach. Lactobacillus is one of the most common of lactic acid bacteria in the gastrointestinal tract [5].

The working principle of probiotics; probiotic bacteria (Lactobacillus and Bifidobacterium) work anaerobically to produce lactic acid resulting in a decrease in the $\mathrm{pH}$ of the gastrointestinal tract that blocks the development and growth of pathogenic bacteria. In contrast to pathogenic bacteria inhabiting the area of the gastrointestinal wall to develop the disease, probiotic bacteria inhabit the gastrointestinal mucosa that also results in changes in the composition of bacteria present in the gastrointestinal tract [6].

Infants aged 0-6 months, just need breast milk (ASI) just as food and beverage main [7]. Breast milk is easily digested and directly absorbed by the baby. Lack of nutrition, allergic, colic, constipation (constipation), danobesitas (overweight) is less likely to occur in babies who consume breast milk [8]. In breast milk, some probiotics can help the colonization process to prevent the development of harmful bacteria in the baby's intestines. This is caused by a special probiotic substance in breast milk that selectively feeds only good bacteria. Some studies suggest that good bacteria in the mother's digestion can move the baby's body through breast milk [6].

Adequate intake of probiotics can prevent babies from certain types of respiratory infections, diarrhea, and can boost the baby's immune system as a whole. In addition to good for infants probiotics are also very good for breastfeeding mothers include: Reducing the risk of infection in the breast, such as mastitis, for women who give birth by cesarean section, probiotics help to restore the condition of the intestine as before, Probiotics can also help restore the body weight of the mother after childbirth [9].

Intestinal microflora is defined as the bacterial flora of the feces because the distal intestinal flora (ileum-colon) is almost identical to that found in feces [10]. Gastrointestinal microflora has several functions such as protein synthesis and vitamins, aids digestion and absorption and serves to inhibit the growth of pathogenic bacteria by producing organic acids, producing bacteriocin as an anti-bacterial and replacing attached bacterial pathogens on the surface of the gastrointestinal epithelium. Under normal circumstances, the number of beneficial microflora is more than the number of pathogenic bacteria. The number of pathogenic bacteria and beneficial bacteria must be in a balanced state to maintain gastrointestinal health. It is important to maintain the balance of intestinal microflora in order to achieve optimal growth and development [6].

In addition to probiotics in breast milk, there is also protection including $\operatorname{IgA}, \operatorname{IgM}, \operatorname{IgD}$, IgG, IgE, Immune, Lactoferrin, lysozyme, Oligosaccharide antibodies which at the time of breastfeeding affect the exposure of microorganisms in the baby's gastrointestinal tract. Furthermore, the baby is given breast milk whereby during probiotic breastfeeding, these immunoglobulin cells and components are transferred to the baby so as to help maintain a good intestinal microflora balance of the baby to maintain the health of the baby's digestive tract, keep the immune system or infant immunity until the baby's physical activity becomes better [11].

Based on this background, researchers wanted to know about the effect of dadiah ice cream on breastfeeding mothers against L.plantarum in infants aged 6-12 months. 


\section{Materials and Methods}

This research uses Equivalent pre-post test with control group design where the measurement of case and control group subject before and after treatment. The ethical document has been reviewed by the research ethics committee of Faculty of Medicine Unand, Padang. Research subjects were breastfeeding mothers who had infants between 6-12 months. Total subjects were 28 people consisting of 14 control groups and 14 treatments received dadiah ice cream.

Bacterial identification is based on the species of lactic acid bacteria found in infant stools. Identification of bacterial strains using a 16sRNA primer followed by sequencing. Isolation of these DNA using Qiamp DNA isolation kit (Qiagen, Inc). Working procedures adapted to the research protocol. Quantification of bacteria was performed using real-time PCR with the hybridization probe technique. In this study, the primers and probes were from the journal according to the species found. Quantification of the bacteria was carried out in 3 stages, i.e., target DNA amplification, making normal curves of target bacteria from known isolates of concentration and calculating target bacterial concentrations.

Data are presented in tables and graphs. Bacterial concentration was performed in the form of CFU / ml. Data analysis using SPSS version 20.0, numerical data were analyzed by using an independent test for normal distribution data.

\section{Results}

The study was conducted on breastfeeding mothers who have babies aged 6-12 months who are in the working area of V Kaum Public Health Center, Tanah Datar. The total subjects meticulously are 28 people. Of the 28 people where 14 people were given dadiah ice cream and 14 other people were given ice cream does not contain dadiah.

\subsection{Identification of infant feces bacteria}

Identification of infant feces bacteria begins with microbiological identification in the form of gram staining and culture. Cultures were performed on MRS, a specific medium against lactic acid-producing bacteria. The results of gram staining showed all the isolates were gram-positive gram. The isolates mixed in the early cultures were separated by colony morphology so that a single isolate was obtained.
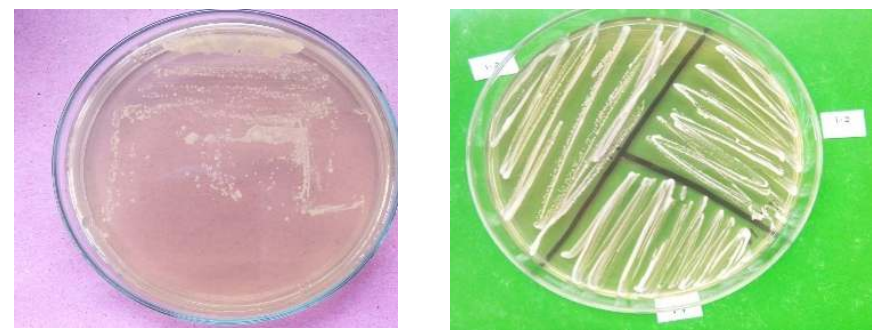

Fig. 1. Isolates of early cultures and subculture products in single colonies

DNA isolation was performed on the feces and continued with amplification using a 16sRNA primer with a size of about $1300 \mathrm{bp}$. The PCR product is further sequenced and aligned using 
BLAST. Based on the sequencing data obtained several species of BAL in infants are Lactobacillus fermentum, Weisselia cibaria, Lactobacillus gasseri, Lactobacillus salivarius, Lactobacillus ducreyi.

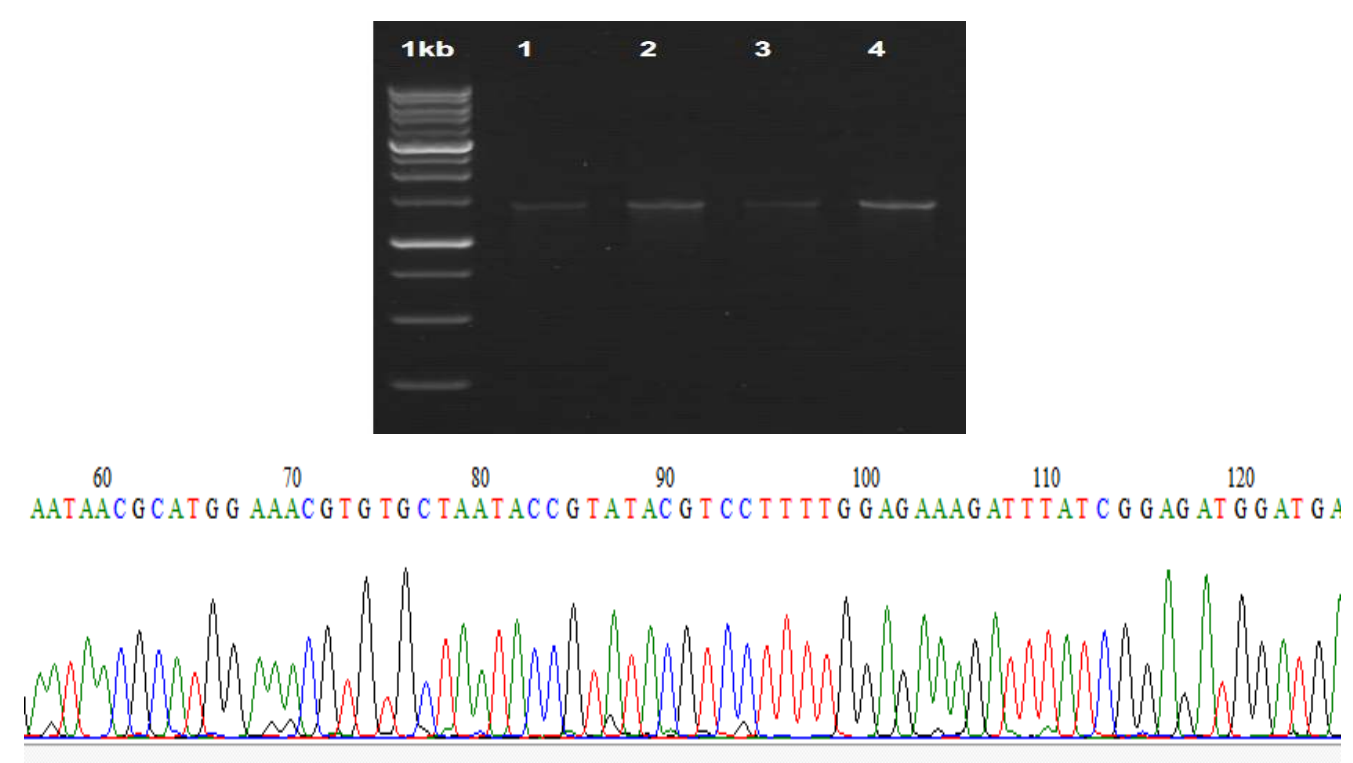

Fig. 2. Results of electrophoresis of PCR products 16sRNA and sequencing

Sequencing data compared with culture results showed the largest proportion of bacteria is Lactobacillus Plantarum, so in the next stage, we use Plantarum as a guide for analysis.

\subsection{The amount of L. Plantarum in infant feces}

To obtain the concentration of bacteria in the feces prepared a standard curve of known bacterial concentrations. In this research, the $\log$ equation of bacteria $(y)=-0.2891 x+10.828$, where $x$ is the cq value obtained from PCR real time machine.

\subsection{The amount of $L$ Plantarum in the treatment group}

In the treatment group, it was found that the mean intestinal microflora of the infant before the dadiah ice cream was given was 4.2 x $107 \mathrm{CFU} /$ gram and after the dadiah ice cream was 8.6 $\mathrm{x} 108 \mathrm{CFU} /$ gram. Statistical analysis showed a significant difference in the amount of L. Plantarum in feces before and after dadiah provided $(\mathrm{p}<0.05)$.

Table 1. Mean of Intestinal L.plantarum of infants aged 6-12 months in breastfeeding mothers given dadiah ice cream.

\begin{tabular}{|c|c|c|c|c|}
\hline Group & $\mathrm{n}$ & $\begin{array}{l}\text { Mean+SD } \\
(\text { CFU/Gram) }\end{array}$ & $\begin{array}{l}\text { Min - Max } \\
\text { (CFU/Gram) }\end{array}$ & p-value \\
\hline Before & 14 & $4.2 \times 10^{7} \pm 7.2 \times 10^{7}$ & $1.2 \times 10^{5}-2 \times 10^{8}$ & 0.001 \\
\hline After & 14 & $8.6 \times 10^{8} \pm 1.3 \times 10^{9}$ & $5.4 \times 10^{6}-5 \times 10^{9}$ & \\
\hline
\end{tabular}




\subsection{The amount of $\mathrm{L}$. Plantarum in the control group}

In the control group, it was found that the average L. of the infant intestinal Plantarum before the dadiah ice cream was given was $2.6 \times 107 \mathrm{CFU} /$ gram and after the ice cream containing no dadiah was $1.3 \times 107 \mathrm{CFU} /$ gram. Statistical analysis showed no difference between the two groups $(\mathrm{p}>0.05)$.

Table 2. Mean of Intestinal L.plantarum of infants aged 6-12 months in breastfeeding mothers given dadiah ice cream

\begin{tabular}{lllll}
\hline Group & $\mathrm{n}$ & $\begin{array}{l}\text { Mean }+ \text { SD } \\
(\mathrm{CFU} / \mathrm{Gram})\end{array}$ & $\begin{array}{l}\text { Min }- \text { Max } \\
(\text { CFU/Gram })\end{array}$ & p-value \\
\hline Before & 14 & $2.6 \times 10^{7} \pm 4.2 \times 10^{7}$ & $1.5 \times 10^{5}-1.3 \times 10^{8}$ & 0.158 \\
After & 14 & $1.3 \times 10^{7} \pm 2.9 \times 10^{7}$ & $1.3 \times 10^{5}-1 \times 10^{8}$ & \\
\hline
\end{tabular}

\section{Discussion}

Dadiah is a fermented buffalo milk product originating from West Sumatra which is a traditional foodstuff. The curd contains potent lactic acid bacteria as probiotics. The probiotic bacteria contained in dadiah is a lactobacillus. At present, the curd is developed with a dadiah ice cream shape that is more tasty and good nutrition content.

This study attempted to identify the most common flora bacteria found in infant feces and assessed the effect of whey cream on lactating mothers on L. Plantarum concentrations in infant stools. Bacterial concentrations were determined using a standard curve designed from known bacterial concentrations.

The results of this study showed a significant increase in the number of L. Plantarum in infant feces after obtaining dadiah iced $(\mathrm{p}<0.05)$ and this condition was not found in the group that did not receive dadiah iced.

Intestinal microflora of newborns between 109-1010 CFU/ gram. The study also showed an increase in the number of intestinal microflora of newborns after being given probiotics [12]. The effect of probiotics on breastfeeding mothers on the number of microbiota Lactobacillus and Bifidobacterium and the immunity response in infants 0-2 years found that there was a difference in the number of Lactobacillus microbiota increased compared to Bifidobacterium ie $2.9 \times 109 \mathrm{CFU} /$ gram and $1 \times 108 \mathrm{CFU} /$ gram [13]. Another study found a significant difference in the number of probiotics of Lactobacillus type between breastfed and formula-fed infants. In breast-fed infants, Lactobacillus accounts for $70 \%$ of total intestinal microflora during infancy, while infants fed only $30 \%$ of Lactobacillus intake in the intestinal tract. So the baby's breastfed gastrointestinal tract will be dominated by beneficial bacteria [14].

One of the colonization phases of the intestinal tract microbiota is the type of diet or food consumed by the baby. At the time of infant sterile intestinal infections of various microbiota, but when eating habits develop following the adult diet, intestinal channel microbiota will change. In breast-fed infants, the baby's intestinal tract contains a large number of lactic acid bacteria such as Lactobacillus and Bifidobacterium. Whereas in infants fed intestinal channel milk more dominated by mixed flora and Lactobacillus and Bifidobacterium less prominent [15]. 
Babies who get breast milk intake will have the number of colonies Lactobacillus and Bifidobacterium in the number of lactic acid bacteria are more than the formula given milk where Lactobacillus and Bifidobacterium in breast milk are affected by the composition of breast milk rich in BAL factors present in probiotics.

Based on conventional microbiological analysis with fecal culture in the laboratory with GLP (Good Laboratory Practices) of GLP (Labor Laboratory) certification during one year period, it was found that intestinal microflora of newborns that activate immune system is Lactobacillus and Bifidobacterium which is found in babies consuming breast milk. Lactobacillus and Bifidobacterium play an important role in activating the baby's immune system, so babies consuming formula are more at risk of allergies and intestinal tract infections. By eating foods rich in Probiotics, it improves the intestinal tract. Bacteria in these probiotics play an important role to stimulate the immune system, help the immune maturation, and protect the body from infection - any type of bacteria in Lactobacillus Fermentum, which acts as an immunostimulant agent and lactobacillus Safaris as an inhibitor of inflammation.

Some of the specific strains of probiotics significantly play an important role in overcoming intestinal problems such as acute diarrhea in children. Invivo is also proven by milk supplementation with probiotic content can significantly decrease clinical symptoms of diarrhea. Probiotics are also able to reduce the histopathological changes caused by viruses and the ability of probiotics to prevent the spread of the virus in the intestine as a result of the effects of probiotic immunity. Probiotics have an important role in the management of intestinal tract disorders [16],[17].

Breastfeeding mothers who consume probiotics then the probiotic content in breastmilk Mother can be transferred to the baby through breast milk. Not only beneficial for the baby for the mother alone probiotics also provide a very large advantage to health. Based on the results of this study it can be concluded that there is a significant difference related to the amount of $\mathrm{L}$. Plantarum before and after the provision of dadiah ice cream in the group receiving dadiah ice cream, and there was no significant difference in the amount of L. plantarum before and after in the group that did not get dadiah ice cream. There was a significant difference in the change in L.plantarum between groups receiving and not getting iced dadiah.

\section{Conclusion}

Based on the results of this study it can be concluded that there is an increase in L.plantarum concentration after the provision of dadiah ice cream in breastfeeding mothers.

\section{References}

[1] Suroso IS, Martono PD, Kameo S, Suradji EW, Koyama H. Effect of probiotic L. Plantarum IS10506 and zinc supplementation on humoral immune response and zinc status of Indonesia preschool children. J Trace Elem Med Biol. 2014; 28:465-9.

[2] Lutter CK and Chaparro CM. Neonatal period: Linking Best Nutrition Practices ay Birth to Optimize Maternal and Infant Health Survival. Food and Nutrition Bulletin. 2009; 30 (2): S215S224

[3] Ramakrishnan U (2010). A Review of the Benefits of Nutrient Supplements during Pregnancy: From Iron-Folic-Acid to Long-Chain Polyunsaturated Fatty Acids to Probiotics. Annales Nestlé (English ed). 2010; 68(1): 29-40 
[4] Rodrigues MAM, Silva DAO, Taketomi EA, Hernandez-Blazquez FJ. IgA production, coliforms analysis and intestinal mucosa morphology of piglets that received probiotics with viable or inactivated cells. Pesq Vet Bras. 2007; 27: 241-245.

[5] Wadstrom T, Ljungh A. Lactic acid bacteria as probiotic. Curr Issues Intest Microbiol. 2006; 7: 73- 90.

[6] Villoslada FL, Debras E, Nieto A, Concha A, Ga'lveze J, Lo'pez-Huertas E, Julio B, Obled C, Xaus J. Oligosaccharides isolated from goat milk reduce intestinal inflammation in a rat model of dextran sodium sulfateinduced colitis. Clin Nutr . 2006; $25: 477-488$.

[7] World Health Organization. Guidelines for evalution of probiotic in food. Report of Joint FAO/WHO Working Group on drafting Guidelines for the evaluation of probiotic in food. London Ontario, Canada, 2002.

[8] Kos B, Suskovic J, Simpraga M, Frece J, Matosic. Adhesion and aggregation ability of probiotic strain Lactobacillus acidophilus M92. J Appl Microbiol. 2003; 94 : 981-987.

[9] Yi SH, Jernigan JA, McDonald LC. Prevalence of probiotic use among inpatients: a descriptive study of 145 U.S. hospitals. Am J Infect Control 2016;44:548-53.

[10] Berggren A, Lazou Ahren I, Larsson N, Onning G. Randomised, double-blind and placebocontrolled study using new probiotic lactobacilli for strengthening the body immune defence against viral infections. Eur J Nutr 2011;50:203-10

[11] Makino S, Ikegami S, Kume A, Horiuchi H, Sasaki H, Orii N. Reducing the risk of infection in the elderly by dietary intake of yoghurt fermented with Lactobacillus delbrueckii ssp. bulgaricus OLL1073 R-1. Br J Nutr 2010;104:998-1006.

[12] Sanchez M, Darimont C, Drapeau V, Emady-Azar S, Lepage M, Rezzonico E, et al. Effect of Lactobacillus rhamnosus CGMCC1.3724 supplementation on weight loss and maintenance in obese men and women. Br J Nutr 2014;111:1507-19.

[13] Senok AC, Ismaeel AY, Botta GA. Probiotics: facts and myths. Clin Microbiol Infect 2005;11:958-66.

[14] Hatcher GE, Lambrecht RS. Augmentation of macrophage phagocytic activity by cell-free extracts of selected lactic acid-producing bacteria. J Dairy Sci. 1993 ;76:2485-2492.

[15] He F, Morita H, Hashimoto H, Hosoda M, Kurisaki J, Ouwehand Ac, Isolauri E, Benno Y, Salminen S. Intestinal Bifidobacterium species induces varying cytokine production. J Allergy Clin Immunol. 2002; 109: 1035-1036

[16] Henker J, Laass M, Blokhin BM, Bolbot YK, Maydannik VG, Elze M, et al. The probiotic Escherichia coli strain Nissle $1917(\mathrm{EcN})$ stops acute diarrhoea in infants and toddlers. Eur J Pediatr 2007;166:311-8.

[17] Clarke TC, Black LI, Stussman BJ, Barnes PM, Nahin RL. Trends in the use of complementary health approaches among adults: United States, 2002-2012. Natl Health Stat Report 2015;79:116. 